\title{
Low carbon development and energy security in Africa
}

Book or Report Section

Accepted Version

Okereke, C. and Yusuf, T. (2013) Low carbon development and energy security in Africa. In: Dyer, H. and Trombetta, M.J. (eds.) International handbook on energy security. Edward Elgar, Cheltenham. ISBN 9781781007891 Available at http://centaur.reading.ac.uk/33210/

It is advisable to refer to the publisher's version if you intend to cite from the work. See Guidance on citing.

Publisher: Edward Elgar

All outputs in CentAUR are protected by Intellectual Property Rights law, including copyright law. Copyright and IPR is retained by the creators or other copyright holders. Terms and conditions for use of this material are defined in the End User Agreement. 


\section{CentAUR}

Central Archive at the University of Reading

Reading's research outputs online 
Low Carbon Development and Energy Security in Africa

Chukwumerije Okereke and Tariya Yusuf

\section{INTRODUCTION}

Energy poverty is without a doubt one of the most critical development challenges facing African countries today. Out of a population of about a billion, over 547 million Africans do not have access to electricity but depend on biomass for their basic energy needs (IEA, 2011). Wide scale energy provision is therefore a vital requirement for achieving the economic growth and development aspirations of African countries. This is more so the case in Sub-Saharan Africa which has the worst poverty in the world (EIA, 2011).

An equally important challenge facing Africa and the rest of the world is how to deal with the problem of climate change which is caused mostly by carbon emissions implicated in energy production and consumption. Climate change, through its impact on drought, desertification, health and extreme weather events, will exacerbate energy poverty in Africa and lead to the further impoverishment of millions (IPCC, 2007a).In fact, worsening energy security problems is one the most critical ways in which climate change is affecting, and will continue to affect Africa (IPCC, 2011).

It is clear therefore that the central development dilemma facing African countries and their development partners today is how to address the problem of climate change while at the same time pursuing the quest for rapid economic growth and universal energy access (IEA, 2011; Sokona et al., 2012). The answer to this dilemma lies, to a large degree, in the concept of low carbon development. Africa has plenty of cheap renewable resources that can be harnessed to achieve the triple wins of combating energy poverty, mitigating climate change and building a low carbon economy. A low 
carbon development path for Africa carries the promise of multiple co-benefits including wider systematic economic resilience, improvement in health condition, resource conservation, energy security, reduced foreign exchange need and reductions in budget deficit (Bowen and Frankhauser, 2011; Diog and Adow, 2011; Khennas, 2012). Indeed, the current situation in many African countries where high cost and carbon intensive energy is imported through distant transcontinental routes is incongruous with reason and basic economics of good development. Pursuing low carbon development options has the potential to facilitate economic integration and market access among African countries while also helping the continent to contribute its quota in helping the global community address the problem of climate change. That said, harnessing cheap renewable energy resources in Africa will require appropriate capital, national regulatory and investment policy frameworks which may not necessarily be easy to achieve. It will also require an equitable distribution of the cost of transition to a global low carbon future, a significant aspect of which will have to come from substantial North-South financial and technology transfer.

\section{ENERGY POVERTY IN AFRICA}

One of the most significant issues affecting development in Africa is poor access to modern energy services. Energy access is critical for meeting many human needs including lighting, heating, cooking and communication. It also plays a central role in driving productive enterprise such as agriculture, transport and industrial activities. The link between energy consumption and economic growth is fairly straightforward and well established (Abanda et al., 2012; IEA, 2011; Kanagawa and Nakata, 2007). For Africa a key feature of the economic landscape is extremely poor access to and low consumption of modern energy. This is despite the fact that Africa has abundant natural 
resources and is a major contributor to world's primary energy oil production. Africa has about 9 per cent of proven world's oil reserve and accounts for about 12 per cent of total world oil production (IEA, 2011). The continent has about 7 per cent and 6 per cent of world's total gas and coal reserves respectively (BP, 2012). There is also abundant natural gas, hydro, solar, biofuel, geothermal and nuclear energy resources. Despite these endowments, Africa with its 14 per cent of global population accounts for just about 3 per cent of world's primary energy consumption (BP, 2012). Africa has the lowest electrification rate of all the world at 26 per cent of households, with as many as 547 million people without access to electricity (EIA, 2011). Accordingly, a vast proportion of people in Africa depend on traditional biomass fuels from woods, agricultural residue and dung for heating and cooking needs. According to IEA reports, more than 80 per cent of Sub Saharan African households amounting to 653 million people use biomass for cooking. This has had devastating consequences for people and the environment. In 2009, more than 1.45 million African lives were lost to household pollution caused by inefficient biomass cooking stoves. Fewer people died from malaria (IEA, 2011).

Figure 21.1 Number of People without Electricity (Actual and Projected) by Region under Current Policies 


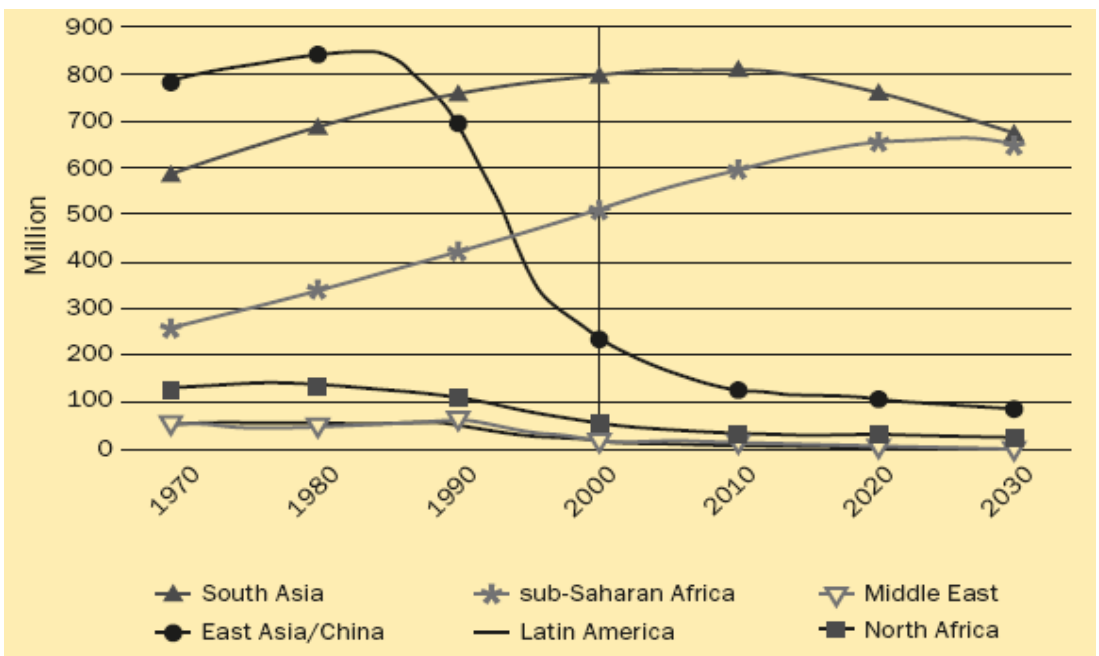

<sc >Source: World Bank (2009). </sc $></$ figure $>$

On current trends less than half of African countries will reach universal access to electricity even by 2050. Generation capacity in Africa at 39 MW per million population is about one-tenth of the levels found in other low income regions of the world. Per capita electricity consumption in Africa (excluding South Africa) averages only 124 kilowatt-hours a year, barely one per cent of the consumption typical in high income countries (EIA, 2011). This is hardly enough to power one light bulb per person for six hours a day. The number of people without electricity is either static or increasing because population growth is outstripping the pace at which households are being connected. In other words, the annual rate of new connections in Africa (less than 1 per cent) is not keeping pace with new household formation (1.9 per cent).

Within Africa there is wide variation across the sub regions. In the recent past, North African countries have made significant advance in dealing with the challenge of energy access leaving the problem mostly for sub-Saharan Africa. For example, two out of three Sub Saharan African (SSA) households live without electricity. In stark contrast, 99 per cent of North African households have electricity supply (IPCC, 2011). Only 14 per cent of rural Sub Saharan African (SSA) households are linked to the grid. 
In comparison, 74 per cent of rural households in Latin America are connected to the national grid (Khennas, 2012).

In Sub-Saharan Africa, East Africa has the lowest consumption of modern energy services per capita and this is in spite of the growth of national economies witnessed in the last decade or so. For example, per capita consumption of electricity in Tanzania is alarmingly low at $65 \mathrm{kWh}$. This represents only about 2.4 per cent of world consumption of 2,751 kWh/per capita (World Bank, 2007).The picture is even grimmer for Uganda. Here, only 10 per cent of the population has access to electricity and the per capita electricity consumption stands at $44 \mathrm{kWh}$. Kenya's per capita electricity consumption is comparatively better. It is estimated to be $128 \mathrm{kWh}$ (UNEP, 2012). But the picture is not much different even for large countries like Nigeria which is widely regarded as one of the two super economies in Africa - the other being South Africa. It is estimated that well over 50 per cent of Nigerian's 152 million population does not have access to electricity (Eleri et al., 2011; Okoro and Chikuni, 2007). The country, which requires a minimum of $10,000 \mathrm{MW}$ of electricity to meet her energy demands currently has a production capacity of just about 3,000 MW. Even though the installed capacity of electricity is much greater than 3,000 MW, infrastructure utilization is historically very poor and power supply has been epileptic as a result of lack of maintenance and unscheduled outages (Oseni, 2012). Investment needed in the power sector by Nigeria to generate anything near the quantity needed is estimated at USD20 billion (Eleri et al., 2010; Okafor, 2008; Okoro and Chikuni, 2007).

While the figures on the number of households connected to the grid provide a very good indication of the extent of the problem, they do not tell the whole story. In reality, a high percentage of those that are connected to the grid do not have regular 
access to electricity due to high frequency of blackouts and unstable power supply. The World Bank estimates that SSA households experienced between 91 and 105 days of blackouts in 2007. There are several instances where communities that have been connected to the national grid actually never get to enjoy electric power supply for more than three months in a year. Frequent outages and load shedding very much characterize the experience of a vast majority of populations and businesses in most sub-Saharan African countries (Akinbami et al., 2001).

High-cost and unreliable energy services in Africa are a significant drag on economic growth and competitiveness in the region. Every year, African households and business spend upwards of USD17 billion on fuel based lighting that is often of poor quality and hazardous (World Bank, 2009). The World Bank further estimates that the economic value of power outages noted above amounts to as much as 2 per cent of GDP for countries affected. This figure according to the International Energy Agency (see Figure 21.1 above) will continue to grow unless new policies and programmes to increase access are implemented.

Beyond low electrification, energy poverty challenges in Africa extends to inefficient and perilous forms of domestic energy for cooking attributable to a lack of modern fuels and clean cookers. Africa currently has the highest energy intensity in the world. It uses far more energy for every dollar of gross domestic product (GDP) than any other region (IEA, 2011). Africa's inefficient energy system is characterized by energy that is imported, expensive, environmentally unsustainable and dependent on coal, oil, wood fuels and natural gas (IPCC, 2011). Massive dependence on imported fossil fuels consumes a high portion of Africa's export earnings. Even Nigeria, the region's largest exporter of crude oil, has to import refined fuels. Fluctuation of oil and 
gas prices further complicate the task of delivering a secure energy supply in the region. Sub Saharan African countries spent 14 per cent of their GDP on fuel imports in 2000 (EIA, 2011). The focus of delivering centralized conventional electricity through thermal power from oil, gas and coal or from large-scale hydropower has not effectively delivered either energy access for poor people or the rate of economic growth that subSaharan African countries aim for (Anozie et al., 2007).

It is generally accepted that for Africa to achieve the millennium development goals (MDG) embodied in sustained economic growth leading to poverty reduction, improved standard of living, adequate and reliable energy services have to be made available. There is a close association between reducing the need for poorer households in developing countries to use biomass for cooking and heating and reaching the MDGs on universal primary education, promoting sex equality and the empowerment of women and reducing under-five child mortality. A rapidly changing climate will however make this task more difficult and further exacerbate energy poverty in Africa (Ebohon, 1996).

\section{CLIMATE CHANGE AND ENERGY POVERTY}

The threat of climate change to humankind and to the planet as a whole has gradually become more evident. Africa is the continent most vulnerable to climate change impacts and the least prepared to deal with its effects (IPCC, 2007b). In fact, Africa is already experiencing severe negative impacts of climate change on its people, environment and economy (IPCC, 2007b). These include among others, prolonged periods of droughts, surface mean temperature increase, reduced agricultural yield, erratic precipitation patterns, flooding, ecosystem collapse, malnutrition, spread of tropical diseases and 
deaths. One of the key ways in which climate change is impacting and will impact Africa is in the worsening problem of energy poverty (IPCC, 2011).

Climate change and energy poverty has an intimate and complex relationship especially in the context of developing regions like Africa. First, it is well known that energy provision is a critical requirement for achieving economic growth and development. Hence, African countries would need to vastly increase their energy generation and consumption in order to reduce poverty, build climate adaptive capacity and achieve their development aspirations (Bowen and Frankhauser, 2011; Sokona et al., 2012). At the same time, it is well known that the vast proportion (up to 82 per cent) of anthropogenic carbon emissions come from energy related activities, including electricity generation, transport, building, and industry (IPCC, 2007b). The paradox then is that the effort to achieve development, which is crucially needed to escape energy poverty and adapt to climate change, could in turn exacerbate the problem of climate change leading to poverty (Okereke and Schroder, 2009). Second and related, the global aspiration to combat climate change has serious implication for available options for energy provisioning in Africa and other developing countries (Ouedraogo, 2012).

One important emerging issue in this regard is the reluctance of many policy makers, international aid agencies and environmentalists to consider the full range of energy options to meet the energy needs of the poor on the grounds of the need for reducing greenhouse gas (GHG) in the atmosphere (Sanchez, 2011). A famous case was the controversy that was generated in 2010 when the World Bank's sought to lend Eskom in South Africa about USD3.75 billion to finance its coal fired power plant investment project at Medupi. Then (and as of now) the contention by many NGOs was 
that the money would have been better used to finance investment in more expensive but less carbon intensive renewable energy projects. Sanchez (2011) has also noted that in some cases this imperative to achieve development in the context of reducing global GHG emissions may result in the use of uncompetitive options to pursue development objectives. One example was where a development agency insisted on using renewable energy system to pump underground water for drinking and farming even when it would have been cheaper to use small diesel engines (Sanchez, 2011). Yet, another scenario which has recently gained currency in literature and public policy relates to situations where efforts to conserve tropical forests in the context of climate change can deny local people access to valuable forest products including wood fuel (Okereke and Dooley, 2010).

Thirdly, climate change, through erratic rainfall, flooding and drought can have a direct impact on energy infrastructure with a serious impact on generating capacity. This has Already been witnessed in various countries in Africa where a drastic decrease in precipitation rates has resulted in severe drought affecting hydropower generation. For example Kenya and Ghana, both of which currently rely heavily on large hydropower dams, have experienced significant power shortages in recent years due to unusually long droughts. Droughts generally lead to massive load shedding and decreased electricity supply with the result of huge economic disruptions and losses (UNEP, 2012). Excessive flooding on the other hand contributes to a rapid build-up of silt in hydropower dams, affecting the amount of water available for electricity generation.

For developing countries in Africa, the recent food, commodities, and oil price shocks - all of which are to some degree a resulting impact of climate change - are 
already having severe implications for energy access particularly among the poorest. The World Bank estimated that the high food, oil, and other commodity prices since January 2007 have reduced the gross domestic product of Africa by 3 to 10 per cent. The terms-of-trade effects of the combined food and energy price increases are in excess of 10 per cent of GDP in more than 15 developing countries, where the room for manoeuvre on the macroeconomic front is limited. With millions of Africans living on the margin between subsistence and starvation, high food and fuel prices may represent a threat to their survival and further heighten energy poverty (UNIDO, 2007). At the same time, poverty and high fuel prices can cause people to engage in high profile deforestation which might in turn exacerbate climate change.

It is important to point out the international justice implication of the above. Historically and currently, Africa's contribution to climate change is very low compared to other world regions (IPCC, 2007). This implies that the changing climate in Africa and associated energy poverty consequences is very much an issue of global justice and equity (Okereke and Schroeder, 2009; Okereke, 2010). Emissions of carbon dioxide in Africa represent only a small fraction (3.6 per cent) of the total $\mathrm{CO} 2$ emissions per year worldwide. In sharp contrast, the contributions from Europe, Latin America and the US are 14 per cent, 20 per cent and 14 per cent respectively. Looking forward, Höhne and Blok (2005) calculate that by 2050 the OECD will be responsible for about 41.7 per cent of global average surface temperature increase due to fossil $\mathrm{CO} 2$ while Africa and Latin America combined would be responsible for just 17.05 per cent. So both in present and future terms, it is the African poor without access to modern energies and who have not shared in the benefits of wealth created from the intensive use of energy 
in the last century that will be the most affected by the impacts of climate change due to greenhouse gas emissions.

In any case, it is clear from the above discussion that nearly all policy measures adopted in order to pursue GHG emission reductions will have implications for the developing countries' economies in general and energy provisioning in particular. Specifically, investments aimed at reducing GHG emissions in Africa may result in reduced expenditure or investments in the energy sector of various African economies (UNEP, 2012). As stated, an urgent challenge for Africa in the light of climate change is how to achieve growth in the context of growing international mitigation policies and the impact these are having on their economies. While, this challenge may appear overwhelming at first, there are indications that Africa could turn climate change into opportunities by pursuing climate resilient low carbon growth strategies. Such strategies will not only enable the continent to manage the development risks associated with global climate mitigation efforts, it will also help them to build a diversified and energy secure and robust local national economies.

\section{LOW CARBON DEVELOPMENT IN AFRICA}

Low carbon development has recently gained currency in academic and policy circles. Although fuzzy and poorly defined, the concept has nevertheless captured public imagination as a possible means of reconciling the need for economic development and climate mitigation. Low carbon development is an imperative for all countries, developed and developing alike, if the global aspiration to combat climate change is to be achieved. Yet, it is widely recognized that the concept has a particular relevance to developing and fast emerging countries where wide scale development initiatives are either needed or already taking place (UNEP, 2012). A cardinal feature of the low 
development paradigm is the notion of decoupling economic growth from carbon emission (Mulugetta and Urban, 2010). In practice, this entails embracing low carbon designs, structures and industrial activities as central parts of development plans. It also requires technological intervention to enhance the energy efficiency of key sectors, implements and practices (Bowen and Frankhauser, 2011).

Given the abundance of renewable energy sources in Africa, it has been suggested that the effort needed to shift production towards cleaner sources may be less than can be expected in some other world regions (Abanda et al., 2012). Africa has significant hydro power potential which is thought to be in the region of $40,000 \mathrm{MW}$ (Kalitsi, 2003; Diog and Adow, 2011). The Democratic Republic of Congo (DRC) and Ethiopia together account for more than 60 per cent of Africa's hydropower potential. Currently, though, only about 20 per cent of this energy source is being utilized. Africa has an abundant reserve of natural gas mostly concentrated in Algeria, Egypt, Libya and Nigeria. The BP statistical Review (BP 2012) estimates that total proven reserve in Africa is 513.2 trillion cubic feet which amounts to about 7 per cent of total world reserve. Only a fraction of this is currently being utilized and a vast portion especially in Nigeria is being flared. It is in fact estimated that gas flaring accounts for about 12 per cent of Nigerian's annual greenhouse gas emission (Anozie et al., 2007).

Estimated geothermal resources on the African continent are around 14GW (EIA, 2011). Of this, only 0.6 per cent has been exploited. Currently, the only countries using geothermal for electricity in Sub-Saharan Africa are Kenya (127MW) and Ethiopia (7MW) (Diog and Adow, 2011). It is thought that some of the most promising undeveloped rift systems are the East African Rift in Mozambique, and in Uganda. Further research is required to explore possible geothermal potentials in Tanzania, 
Eritrea and Zambia (Sokona et al., 2012). In 2007, Africa had about 476MW of installed wind energy generating capacity; a significantly low proportion of the estimated SubSaharan Africa-wide capacity (93,000MW) (Okoro and Chikuni, 2007). Countries like Djibouti, Eritrea, Mauritania and Madagascar among others experience strong wind speed which can be readily converted into useful energy. The Sub-Saharan African countries are well exposed to sunlight with some of the highest solar intensities in the world (Wolde-Rufael, 2009). Northern and southern Africa, particularly the Sahara and Kalahari deserts, have particularly promising conditions for concentrated solar plants for large-scale power production. Kenya has made good strides towards the utilization of solar with more than 30,000 very small solar panels, each producing 12 to 30 watts sold annually. It is the world leader in the number of solar power systems installed per capita (Abanda et al., 2012). However, to date, only South Africa is generating appreciable solar thermal power $(0.5 \mathrm{MW})$ in the Sub-Saharan region. Africa has vast land mass which can be farmed to produce biofuel in a sustainable manner (Akinbami et al., 2001; Amigun et al., 2011) Countries with suitable land include South Africa Angola, Zambia and Mozambique among others.

In general, with adequate economic, technological and governance infrastructure a vast portion of African energy could be produced from clean and low carbon sources. This of course is not to suggest that the exploitation of fossil fuel will have to be completely abandoned. Nor is it the case that all the energy sources mentioned above do not have social and environmental impacts. It is general knowledge that in most cases, achieving energy security requires that countries strive to maintain a balance mix of energy sources in their portfolio (Sokona et al., 2012). 
On the consumption side, low carbon development would require significant changes in values especially with respect to consumption behaviour and patterns. For Africa then, the goals of low carbon development should be to: (a) achieve energy security by significantly enhancing access and reducing reliance on imported fuels; (b) contribute to tackling climate change by avoiding high profile emission in the path to economic development; (c) achieve diversified, equitable and climate resilient economic growth; and (e) realize effective climate adaptation. It is apparent that achieving low carbon development would have far reaching implications for governance and institutional design. For example the internalization of environmental costs of growth would require appropriate pricing of goods and services through a range of policy and economic measures targeting both the production and consumption sides. These would include national and sub national strategies, and master plans, targets, taxes, subsidies, infrastructure and public awareness campaigns.

\section{BENEFIT OF LOW CARBON DEVELOPMENT FOR AFRICA}

The concept and practice of low carbon development in Africa implicate a number of opportunities and threats. Some of these will resonate with other developing countries and some will be specific to Africa with its unique set of resource-base, technical capacity, financial situation. One threat of low carbon development to Africa would be if the approach impedes economic growth by requiring African countries to bear a disproportionate financial burden relative to business as usual development approach (discussed further below). Another would be if commitment to low carbon development results in unnecessary intrusion into the domestic policy processes by foreign actors. That said, there are evidently several reasons while it is in the interest of African governments to embrace and pursue low carbon development. Below, we sketch some 
of the pertinent benefits of low carbon development for Africa. In doing so, we bear in mind that Africa is a very diverse continent and that a number of points discussed here may not be equally applicable to all the countries within the continent.

The first obvious potential benefit of low carbon development is that the approach provides an opportunity for African countries to build more resilient and diversified economies. Many African countries can make their economies more resilient by moving away from conventional single source energy generation towards a more diversified energy portfolio. Countries that get their energy from a mix of sources would naturally be far less vulnerable than those that rely on single sources. Specifically, low carbon development has the potential to help African countries reduce the economic vulnerability associated with dependence on oil (Okereke and Tyldesley, 2011). Almost one-third of African countries (15) are landlocked with no access to the ocean or seas. Many of these are oil importing countries with no proven oil reserve. Examples of such landlocked countries include Botswana, Burkina Faso, Burundi, Central African Republic, Chad, Ethiopia, Malawi, Mali, Niger, Rwanda and Uganda. In the absence of directly accessible oceans and seas, these countries transport crude and refined oil by road over very long distances. Oil is not only an expensive commodity, but one that is uniquely prone to dramatic price spikes. The dependence of these countries on imported diesel and heavy fuel oil means that their economies are very vulnerable to highly fluctuating oil prices. Furthermore, it also implies that the country's electricity generation is firmly tied to insecure oil sources. Oil price spikes directly affect GDP, and in oil-dependent countries the effect can be quite high. On average, it is estimated that every 10 per cent increase in the oil price results in a global drop in GDP of around 
0.2 per cent (Owen et al., 2010). This figure is much higher for many African oil importing countries.

Economic resilience and security can also be enhanced through a range of other sectoral measures and policies widely associated with the concept of green growth such as low carbon development cities and transport. In urban design, for example, countries that opt for dense and compact cities with ample allowances for buses and cycle routes are likely to have both economic and social advantages over those that favour extensive sprawls with very little and expensive integration. Low carbon houses can save energy and help reduce demand on national grid. The main source through which African countries contribute to climate change is currently through land use and deforestation (IPCC, 2007a). Low carbon development would have to incorporate effective forestry and land use management (Bowen and Frankhauser, 2011). This should help to protect the natural environment and reduce the vulnerability to flash flooding and destruction caused by wide fire.

Shifting away from inefficient biomass energy to modern sources would also help eradicate poverty and increase economic growth and development. Cleaner energy sources can enhance the adaptive capacity of households to climate change with several important co-benefits. For example using clean cooking stoves and solar lighting will reduced the need to walk large distances to collect firewood. Accordingly, women and children who are usually responsible for these tasks will have more time in the day to engage in productive activities such as trading, household duties or educational activities. Increasing the amount of time for such tasks can support gender equality in the home, and the wider socio-economic benefits associated with empowering marginalized groups such as improved access to community decision-making processes 
(Diog and Adow, 2011). Renewable energy can be particularly suitable for rural and remote areas where, transmission and distribution of energy generated from fossil fuels can be difficult and expensive. Producing renewable energy locally can offer a viable alternative. In such situations, renewable energy can also contribute to education, by providing electricity to schools.

In addition to reducing wider economic vulnerability related to oil price fluctuations, the purist of low carbon development can specifically increase African countries' energy security. Many African countries currently depend on very high cost imported electricity to meet their power needs (World Bank, 2011). Paradoxically, in most cases these countries have abundant renewable sources that could easily be harnessed to meet internal energy demands. In fact with good planning and targeted investment, these countries could eventually be net energy exporters. However, current reliance on externally sourced energy not only implies that scare financial resources are spent on the importation of electricity; it also results in huge insecurity in energy supply. Energy insecurity is further exacerbated by the fact that supplies in some cases come from countries and regions that are politically unstable. Currently, Morocco is the largest energy importer in northern Africa. Morocco produces small volumes of oil and natural gas from the Essaouira Basin and small amounts of natural gas from the Gharb Basin (UNIDO, 2007). However, over 90 per cent of its energy resources come from external sources. Much of these imports are transcontinental from Spain via cables laid beneath the sea and across the Strait of Gibraltar. It is estimated that the country's total yearly costs for energy imports range from USD1 to 1.5 billion. With the increase in oil prices in 2005 the cost of import rose to approximately USD2 billion resulting in a huge budget deficit for the country (UNEP, 2012). 
Another high energy importing county is Togo which imports as much as 80 per cent of its electricity. Out of a total consumption of 726 GWh in 2006, Togo imported $505 \mathrm{GWh}$ mainly from Ghana with additional imports coming from Nigeria and Ivory Coast. Zimbabwe imports up to 400MW of electricity from neighbouring countries including Zambia and the Democratic Republic of Congo. In 2008 the country experienced wide power cuts because an accumulated debt of about USD100 million prevented it from importing larger amounts of electricity. Similarly, also in 2008 Botswana and Namibia, both of which imports over 50 per cent of its electricity from South Africa, were hard hit when an internal energy crisis in South Africa forced Eskom to ration its internal supplies and drastically reduce the amount exported to neighbouring countries. Drained by five principal rivers including the Zambezi, Mozambique is richly endowed with considerable hydropower potential. This has been estimated at 12,500 MW, with a corresponding annual energy generation potential of $60,000 \mathrm{Gwh}$ per year. However, so little of these resources have been exploited. Hence, up to 70 per cent of the country still depends on inefficient and unsustainable biomass sources for energy (World Energy Outlook, 2012).

In general, energy sources such as river basins in Africa are under-utilized, with only 20 per cent of the total potential of hydropower plants under use (Kalitsi, 2003; World Bank, 2011). Mozambique, Lesotho and Swaziland, all of which have abundant renewable resources, continue to rely on South African Eskom for significant amount of their energy needs. Other heavy electricity importing African countries include Egypt, Niger, Namibia, Tanzania and the Republic of Benin.

It has to be acknowledged that there are instances when it is cheaper for a country to import rather than produce its own electricity. Furthermore, some have 
argued that regional power 'pooling' schemes provide the benefit of scale and as such could help solve African's energy challenges (Khennas, 2012). However, cheap importation and power pooling should not be seen as substitutes for developing incountry energy sources, especially when this can be done from abundant renewable and sustainable sources. Currently though, far too many African countries are either importing from very insecure sources or relying on thermally generated electricity to meet their energy needs.

However, the high price of oil means that electricity generated using oil-based generators is very costly and must be subsidized by the government in order to make it accessible to consumers. Even so, many African countries still pay exorbitant prices for their electricity. This is unsustainable especially in the context of very limited resources, high budget deficit and spiralling external debt. The purist of low carbon development, if well planned, could help lower the cost of energy in many African countries. On 1 July 2008 Namibia and Botswana increased their electricity tariffs by 18.6 per cent and 20.4 per cent respectively and warned that prices will continue to rise. These increases had to do with the need to offset the high cost of electricity importation from South Africa. In 2005 the government of Rwanda spent around 8.4 billion RwF (USD13,356,000) on fuel for electricity generation which produced 55.2 GWh. This is in comparison to 1.5 billion RwF (USD2,385,000) spent on $86 \mathrm{GWh}$ of imported electricity from regional hydropower stations. At the same time electricity prices in Rwanda rose from 82 RWF (USD0.13) in 2005 to 112 RWF (USD1.78) in 2006 as the government struggled to cover the high cost of thermal generation and importation (MINIFRA GoR, 2008). 
A further incentive to move away from a fossil fuel-based economy is the effect that the high level of imports has upon African countries' trade deficit. Many African countries that have huge budget deficits spend large amounts of their foreign exchange on oil importation. The current situation, where the import of oil-based fuel for electricity generation and transport continually saps scarce foreign reserves, is not sustainable for long-term economic development. It has been suggested that in 2008 Ethiopia spent up to 96 per cent of foreign earnings on oil import. With the extraordinary rise in oil prices within this period, it is no wonder that inflation soared to as high as 39.4 per cent. Given the very low purchasing power of the African population, high electricity costs are far from ideal. In addition, high electricity costs discourage industries and businesses wishing to set up in the continent. Utilizing domestic renewable energy resources would allow cheaper electricity generation which would enable greater electricity access.

Lastly, low carbon development will help Africa to prevent what is commonly known as carbon lock-in. Carbon lock-in refers to a situation where a high carbon infrastructure in a country inhibits drive and options to pursue alternative energy sources. Many African countries are currently investing or making serious plans to commit large sums of money to develop their energy infrastructure. With the rapid economic growth experienced in the last 10 years massive investments are also being made or planned in other development infrastructure such as roads, railways, airports, and cities. In general, these infrastructures have an average life span of about 40 years and buildings can last much longer than this. The implication is that decisions made today about the types of power plants, roads, railways and buildings funded or constructed will have carbon and energy implications for up to 40 or 50 years at least 
from now. In other words countries can be 'locked-in' to a high carbon or energy pathway by making wrong or short-sighted decisions on which development plans they adopt. By thinking through future energy and carbon implications of decisions and adopting low carbon alternatives, African countries could avoid high carbon lock-in while continuing to develop in a sustainable fashion.

The World Bank and OECD estimates that a total of USD40.8 billion a year in investments is needed for Africa's power sector, with USD26.72 billion for capital expenditure and USD14.08 billion for operations and maintenance (World Bank, 2009). For the IEA Africa needs about USD344 billion to create additional electricity capacity, upgrade installed equipment and extend transmission and distribution networks to households and factories. Countries that are already spending large sums of monies in their energy sectors include South Africa, Nigeria, Botswana, and Namibia among others.

The government of South Africa estimates that just keeping up with growing demand from industries and the population will require doubling its generating capacity by 2025 at a cost of USD171 billion. Of this, the government plans to spend up to USD45 billion by 2013. Between 2000 and 2007 the Nigerian government under President Olusegun Obasanjo spent about USD16 billion to revamp its power sector. With precious little achieved, the present government has recently pledge to spend USD5.7 billion over the next four years on the power sector. Botswana is spending USD28 billion to construct an integrated coal mine and power station in Mmamabula that could generate 4,800 megawatts (MW) for about 40 years. Zambia is estimated to need USD billion to raise power output to meet its expanding demand and Rwanda has pledged to invest up to USD 4.74 billion in its energy sector between now and 2017. 
A quick look at energy development strategy of many African countries however indicates that for the most part these countries are investing or planning to invest their money on conventional hydrocarbon-based generating facilities rather than on cutting edge low carbon technologies. This is, in a sense, very understandable as these countries are concerned about the high cost of low carbon technologies especially given the difficulty of raising finance from the public and private sector. Perhaps the most recent high-profile example is the 4,800MW Medupi coal-fired power plant that is being constructed by the South African government with financial assistance from the World Bank. When the plans by the South African government to borrow about USD3.75 billion came to light, many green NGOs argued that the money should have been better spent towards generating from renewable sources such as wind and solar. However, South Africa argued that investing in renewable sources will cost much more and generate fare less electricity than a coal power plant. Given the urgent need to increase supply to support rising demand and economic growth, the country felt it had little option than to commit to building the high carbon power plant. <a>6 CHALLENGES TO LOW CARBON DEVELOPMENT AND ENERGY SECURITY IN AFRICA

Achieving low carbon development and energy security in Africa will not be easy. The pursuit of low carbon growth poses a challenge for countries all over the world and there are reasons to believe that these challenges may be particularly acute for African countries. One of the most obvious and frequently cited obstacles that may hinder Africa from harnessing the advantages of green growth is lack of finance. Although technological advances that help lower their costs are being made, clean energy in most cases still costs far more than its conventional alternatives. For example, figures from 
the 2012 report of the Energy Information Administration (EIA) of the US Department of Energy (DOE) suggest that the average capital cost of energy from conventional coal, solar thermal and offshore wind are USD65.8 million MW/h, USD204.7 million MW/h and USD300.6 million MW/h. Even when one factors in the operation and maintenance, fuel costs and transmission investment, all of which are in most cases lower for clean energy, the average total system costs of renewable technologies are still mostly higher than the conventional sources. Generating from renewable sources may also have benefits such as those related to health. However, their costs remain mostly 'frontloaded relative to their benefits' (Bowen and Frankhauser, 2011, 149).

There are of course a number of renewable options such as low head hydro and biomass that are economically competitive especially as a means of supply to sparsely populated rural communities, but even these may require technical assistance and the correction of market failures which may be difficult for many African countries to deliver. Moreover, even when there are strong long-term economic and environmental arguments for investing in clean energy, the notion might persist that in taking a low carbon route, Africans are paying a price imposed on them by foreign governments whose main interest is global climate mitigation. These are some of the main reasons why the provision of adequate and predictable finance and technical assistance by developed countries are absolutely essential in encouraging African countries to embrace low carbon growth paths.

Unfortunately, it is well known that current financial and technical support from the developed countries is far too low compared to what is needed. The Global Environmental Facility established in 1991 serves as the main operating entity for the international climate regime and has the longest track record on environmental funding. 
However, it received just over USD1 billion during its fourth replenishment period (2006-2010). Similarly the other two funding sources within the convention, the Least Developed Countries Fund (LDCF) and the Special Climate Change Fund (SCCF) (both also administered by GEF), have only disbursed USD108 million and USD80 million respectively since their inception in 2002 (Sokona et al., 2012). These figures represent a tiny fraction of what is needed to help developing countries adequately invest in low carbon development and energy security. To compound matters, African countries, mainly because of poor capacity and their position in the global economic structure, have not been the favourites in attracting multilateral and private sector climate finance. Fast-start finance agreed at Copenhagen in 2010 was just USD10 billion per year up until the end of this year; with a long-term goal of mobilizing USD100 billion per year by 2020 . And while this may not be enough, it is doubtful that the global North will commit the amount of money required to meet this ambition.

In addition to the general lack of climate funding, there is also an indication that availability of finance is not linked to what is actually needed or to where it is most urgently needed (Diog and Adow, 2011). Rather, climate finance delivered has reflected the political preferences of developed countries, and the 'low-hanging fruits' opportunities offered by the higher emitting, middle income countries, particularly India and China (Diog and Adow, 2011). It is therefore imperative that adequate and predictable funding is available in order to incentivize low carbon development in Africa. A good illustration of the problem of lack of finance can be found in Rwanda. The Government of Rwanda has ambitious plans to develop its energy sector as a wider plan for achieving low carbon and climate resilient development. Up to 90 per cent of Rwandans have no access to electricity. Of the 20 per cent living in urban areas only 
about 25 per cent are connected to the national grid. And at about $44 \mathrm{kWh}$ per capita per year Rwandan electricity consumption per capita is among the lowest in the world. The Energy Sector National Policy and Strategy set out the aim of installing a total of 1,000MW electricity generation capacity by 2017 (up from $85 \mathrm{MW}$ at present). This expansion of electricity generation capacity is planned to come from four main sources; geothermal (310MW), hydropower (300MW), methane (300MW) and peat (100MW). It is planned that a rapid national grid expansion programme will accompany this increase in generation capacity. The grid will be extended by $2,100 \mathrm{~km}(700 \mathrm{~km}$ of $\mathrm{HV}$ and 1,400 of MV), increasing the number of connections to $1,200,000$ up from 175,000 today (Safari, 2010). The aim of this extension is to enable 50 per cent of the population access to the national grid by 2017. In addition, by 2017 the GoR plans to ensure that all health centres, local administration offices and all schools in the country have access to electricity, either off or on grid (Eggoh et al., 2011). The increase in access to electricity is intended to provide alternatives to traditional sources of energy, hopefully reducing the dependence upon biomass and limiting risks of deforestation. The target is to reduce the use of biomass from 86 per cent of primary energy use today to 65 per cent in 2017. This will also be accompanied by efficiency measures such as improved cooking stoves. Alternatives such as biogas will also be introduced.

The big challenge however is that the energy generation and access plan is estimated to cost around USD5 billion. To put this in context, the entire budget for Rwanda including both recurrent and domestic spending for the fiscal year 2009/10 was USD1 billion. And of this figure, donor support accounted for about 41 per cent. One can immediately see the difficulty faced by the country in overcoming the problem of energy access which is fundamental to economic growth. 
While lack of international climate finance is a major factor limiting low carbon energy secure future for Africa, it is important to stress that this is only one side of the coin. The other is widespread lack of technical capacity and good governance in Africa. There is an abject paucity of technical skills needed to design and implement conventional development projects, let alone cutting edge low emission growth plans (Okereke and Tyldesley, 2011). The majority of African countries have critical capacity gaps in all the key phases involved in the low carbon development delivery chain from conception, through design and planning to implementation. Many governmental ministries have just one or two experts who have to draft or vet project proposals, study sophisticated engineering designs, conduct rigorous economic analysis, negotiate complex legal contracts and undertake the other several highly technical tasks associated with policy development and implementation.

Closely related to, and perhaps the primary reason for poverty, is the problem of poor governance. Decades of poor governance in Africa have resulted in underinvestment in education, human capital, and research and technology development. Similarly, there is widespread underinvestment in fundamental development infrastructure upon which to leverage green growth policies. Lack of infrastructure, poor institutions and widespread corruption provide the platform for the dominance of the energy market by monopolies which are often controlled by a few elites. These monopolies are usually not interested in widening energy access but have been known to actively block the market entry of green energy providers. The result is lack of private capital, pervasive market failure, chaotic regulatory environment and usually high costs for investment in clean energy. To achieve energy security and low carbon development, then, African countries will need to undergo radical governance 
reforms aimed inter alia at minimizing corruption, increasing technical and human capacity, correcting market failure and boosting investment in infrastructure and technology development.

\section{CONCLUSION}

The concept of low carbon development offers plenty of prospects for Africa to grow its economy, achieve energy security while contributing its own quota in the global effort to fight climate change. Given the critical importance of modern energy to wellbeing and to economic development in general, achieving universal energy access should definitely be the priority of African countries. However, there is no reason why Africa must follow the development path towed by the West with its negative impact on environment and humankind. Rather emphasis should be on harnessing the abundant renewable natural resources present all across the continent. However achieving low carbon development would require the massive upscale of climate and clean energy finance, large-scale investment in technology and human capacity as well as radical governance reforms. Africa has the right to expect significant financial assistance from the international community to offset the additional cost associated with low carbon development. It currently makes an insignificant contribution to the global carbon pool while bearing the brunt of much of the negative impact of climate change. Indeed, the World Bank (2010) calculates that scaling up access to electricity access in Africa would add only a small fraction of projected global emissions from 1.5 per cent of global annual energy related $\mathrm{CO} 2$ emissions today to 2-3 per cent of global emissions by 2050 . Provisions of much needed basic energy services to the poor would therefore contribute only 1 per cent to global CO2 emissions (World Bank, 2011).The poor 
deserves basic energy services like everyone else. Moreover, they have made little contributions to climate change. Global justice and equity is therefore at the heart of the debate about climate change, energy security and climate mitigation.

\section{REFERENCES}

Abanda, F., A. Ngombe, R. Keivani and J.H.M. Tah (2012), 'The link between renewable energy production and gross domestic product in Africa: A comparative study between 1980 and 2008', Renewable and Sustainable Energy Reviews, 16, 21472253.

Akinbami, J.F.K, M.O. Iloori, T.O. Oyebusi, I.O. Akinwumi and O. Adeoti (2001), 'Biogas energy use in Nigeria: current status, future prospects and policy implications', Renewable and Sustainable Energy Reviews, 5, 97-112.

Amigun, B., J.K. Musango and W. Stafford (2011), 'Biofuels and Sustainability in Africa', Renewable and Sustainable Energy Reviews, 15, 1360-1372.

Anozie, A., A.R. Bakare, J.A. Sonibare and T.O. Oyebisi (2007), 'Evaluation of cooking energy cost, efficiency, impact on air pollution and policy in Nigeria', Energy, 32, 1283-1290.

Bowen, A and S. Frankhauser (2011), 'Low-Carbon development for the least developed countries', World Economics, 12 (1), 145-162.

BP 2012, Statistical Review of World Energy, available at http://www.bp.com (accessed 16 November 2012).

Diog, A., and M. Adow (2011), 'Low carbon Africa: Leap frogging to a greener future', available at http://www.christainaid.org.uk/images/low carbon/Africa.pdf (accessed 15 November 2012). 
Ebohon, O.J. (1996), 'Energy, economic growth and causality in developing countries', Energy policy, 24 (5), 447-453.

Eggoh, J.C., C. Bangake and C. Rault (2011), 'Energy consumption and economic growth revisited in African Countries', Energy Policy, 39, 7408-7421.

Eleri, E., O. Ugwu and P. Onuvae (2011), 'Low Carbon Africa: Leap frogging to Green future: Nigeria', available at http://www.christainaid.org.uk/resources/policy/climate/low-carbon-africa (accessed 17 November 2012).

EIA, Energy Information Administration (2011), 'International Energy Statistics’ available at http://www.eia.gov/ipdbproject/IEDIndex3.cfm (accessed 20 November 2012).

Höhne, N. and K. Blok (2005), 'Calculating historical contributions to climate change: discussing the 'Brazilian proposal”', Climatic Change, 71, 141-173. IPCC (2007a), 'Climate Change 2007 - Impacts, Adaptation and Vulnerability', Contribution of Working Group II to the Fourth Assessment Report of the IPCC, Cambridge: Cambridge University Press.

IPCC (2007b), 'Climate Change 2007 - Mitigation of Climate Change', Contribution of Working Group III to the Fourth Assessment Report of the IPCC, Cambridge: Cambridge University Press.

IPCC (2011), 'Renewable energy sources and climate change mitigation. Summary for policy makers', Special Report of the IPCC, Cambridge: Cambridge University Press. IEA, International Energy Agency (2010), 'World Energy Outlook', available at http://www.iea.org/publications/freepublications/publication/name,27324,en.html (accessed 3 March 2013). 
IEA, International Energy Agency (2011), 'Statistics and Balances', available at http://www.iea.org/stats/index.asp (accessed 20 November 2012).

Kalitsi, E.A. (2003), 'Problems and Prospects for hydropower development in Africa', available at www.un.org/esa/sust/dev/sdissues/energy/op/nepadkalitsi.pdf (accessed 20 November 2012).

Kanagawa, M. and T. Nakata (2007), 'Analysis of the energy access improvement and its socioeconomic impacts in rural areas of developing countries', Ecological Economics, 62.

Khennas, S. (2012), 'Understanding the political economy and key drivers of energy access in addressing national energy access and policies: African Perspective, Energy Policy, 47, 21-26.

MININFRA GoR (2008), 'National Energy Policy and National Energy Strategy 20082012', Kigali.

Mulugetta, Y and F. Urban (2010), 'Deliberating on low carbon development', Energy Policy, 38, 7546-7549.

Okafor, E. (2008), 'Development crisis of power supply and implications for Industrial Sector in Nigeria', Stud Tribes Tribals, 6 (2), 83-92.

Okereke, C. (2010), 'Climate justice and the international regime', WIREs Interdisciplinary Review, 1, May/June, 462-474.

Okereke, C. and K. Dooley (2010), 'Principles of justice in proposals and policy approaches to avoided deforestation: Towards a post-Copenhagen climate agreement', Global Environmental Change, 20, 82-95.

Okereke, C. and H. Schroeder (2009), 'How can the objectives of justice, development 
and climate change mitigation be reconciled in the treatment of developing countries in a post-Kyoto settlement?', Climate and Development, 1, 10-15.

Okereke, Chukwumerije and Sally Tyldesley (2011). 'Low Carbon Africa: Rwanda', in Alice Diog and Mohamed Adow (ed.), 'Low carbon Africa: Leap frogging to a greener future', available at http://www.christainaid.org.uk/images/low carbon/Africa.pdf (accessed 15 November 2012).

Okoro, O.I. and E. Chikuni (2007), 'Power Sector reforms in Nigeria: Opportunities and Challenges', Journal of Energy in Southern Africa, 18 (3), 52-57.

Oseni, M. (2012), 'Households' access to electricity and energy consumption pattern in Nigeria', Renewable and Sustainable Energy Reviews, 16, 990-995.

Ouedraogo, N. (2012), 'Energy Security, Global Climate change and Poverty. Interrelated Challenges of energy poverty, energy security and climate change mitigation and adaptation in Africa', available at http://www.iaeu2012.it (accessed 18 November 2012).

Owen, N.A., O.R. Inderwildi and D.A. King (2010), 'The Status of Conventional World Oil Reserves - Hype or Cause for Concern?', Energy Policy, 38 (8), 4743-4749.

Safari, B. (2010), 'A review of Energy in Rwanda', Renewable and Sustainable Energy Reviews, 14, 524-529.

Sanchez, T. (2011), 'Climate Change and Energy Poverty in Africa', Africa Energy Yearbook 2011, available at http:// www.practicalaction.org (accessed 12 November 2012).

Sokona, Y., Y. Mulugetta and H. Gujba (2012), 'Widening energy access in Africa: Towards Energy Transition', Energy Policy, 47, 3-10. 
UNIDO (2007), 'Powering Industrial Growth-the challenge of Energy Security issues for Africa', available at http//www.ofid.org (accessed 17 November 2012).

UNEP (2012), 'Financing renewable energy in developing country. A study and survey', UNEP, February.

Wolde- Rufael, Y. (2009), 'Energy consumption and Economic growth: The experience of African countries revisited', Energy Economics, 31, 217-224.

World Bank (2009), ‘Africa Energy Poverty.G8 Energy Ministers Meeting’, available at http://www.g8energy2009.it (accessed 15 November 2012).

World Bank (2011), 'Energy in Africa. An Overview', September, available at http://web.worldbank.org (accessed 5 March 2013).

World Energy Outlook (2011), 'Executive Summary', available at http://www.iea.org/publications (accessed 12 November 2012). World Energy Outlook (2012), 'Early Release Overview', available at http://www.iea.org/publications (accessed 12 November 2012). 
